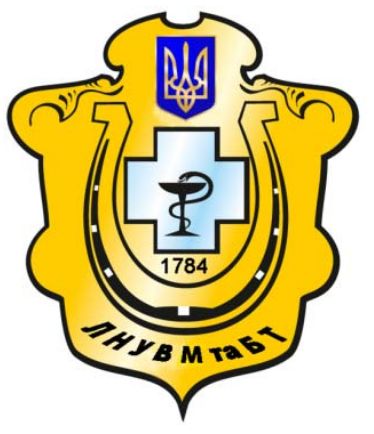

Науковий вісник Львівського національного університету ветеринарної медицини та біотехнологій імені С.3. Гжицького

Scientific Messenger of Lviv National University of Veterinary Medicine and Biotechnologies named after S.Z. Gzhytskyj

doi:10.15421/nvlvet7127

ISSN 2413-5550 print

ISSN 2518-1327 online

$\underline{\text { http://nvlvet.com.ua/ }}$

УДК 636.2.034:618.19-002:575

\title{
Алельний поліморфізм гена BOLA-DRB3.2 в зв'язку з типами вивідної системи вимені та маститами корів української чорно-рябої молочної породи
}

\author{
Т.М. Супрович, М.П. Супрович, Т.М. Карчевська, І.О. Чорний, В.А.Чепурна \\ kokas2008@ukr.net
}

Подільський державний аграрно-технічний університет, вул. Тараса Шевченка, 13, м. Кам'янець-Подільський, 32316, Украӥна

\footnotetext{
В статті наведено результати порівняння двох видів маркерів пов 'язаних зі сприйнятливістю (стійкістю) корів до маститів. Попередніми дослідженнями встановлено, що такими маркерами можуть слугувати алелі гену BOLA-DRB3.2 морфологічні особливості будови вимені, а саме - тип вивідної системи: розсипний або магістральний. Дослідження проведено шляхом виявлення алельного спектру і типу вивідної системи вимені у 47 корів української чорно-рябої молочної породи. У 28 тварин в генотипі присутні «інформативні» алелі, які вказують на асоціацію з маститом чи резистентністю до даного захворювання. У сприйнятливих до захворювання корів розсипний тип виявлясться у половини тварин. Для здорових корів більш характерним є магістральний тип вивідної системи (35,7\%). У 9 корів з магістральним типом вивідної системи в генотипі виявляються лише «позитивні», а у 11 тварин з розсипним типом - лише «негативні» алелі, щьо складає, відповідно, 32,1 та 39,3\%. Порівнянням наявності двох видів маркерів в групах здорових і сприйнятливих тварин встановлено два переважаючих варіанти:

- у здорових тварин найчастіше зустрічаються магістральний тип і хоча б один алель пов'язаний зі стійкістю до маститів (9 випадків);

- у хворих тварин найчастіше зустрічаються розсипний тип і хоча б один алель пов'язаний зі сприйнятливістю до маститів (11 випадків).

Висока частота виявлення даних варіантів вказує на те, що існують закономірні зв'язки між типом вивідної системи, алелями BoLA-DRB3.2 і маститами.

Ключові слова: корови, мастит, головний комплекс гістосумісності, ген BOLA-DRB3.2, алелі, тип вивідної системи, вим'я, чорно-ряба порода.
}

\section{Аллельный полиморфизм гена BOLA-DRB3.2 в связи с типами выводной системы вымени и маститами коров украинской черно-пестрой молочной породы}

\author{
Т.М. Супрович, Н.П. Супрович, Т.М. Карчевская, И.А. Чорный, В.А.Чепурна \\ kokas2008@ukr.net
}

Подольский государственный аграрно-технический университет, ул. Тараса Шевченко, 13, г. Каменеи-Подольский, 32316, Украина

\footnotetext{
В статье приведены результаты сравнения двух видов маркеров, связанньх с восприимчивостью (устойчивостью) коров к маститам. Предыдущчими исследованиями установлено, что такими маркерами могут служить аллели гена ВоLАDRB3.2 и морфологические особенности строения вымени, а именно - тип выводного системы: рассыпной или магистральный.
}

\section{Citation:}

Suprovych, T., Suprovych, N., Karchevska, T., Chornyy, I., Chepurna, V. (2016). Allelic polymorphism gene BOLA-DRB3.2 in connection with the types of excretory ducts udder and mastitis cows Ukrainian black-pied dairy breed. Scientific Messenger LNUVMBT named after S.Z. Gzhytskyj, 18, 3(71), 117-123. 
Исследование проведено путем выявления аллельного спектра и типа выводного системы вымени у 47 коров украинской черно-пестрой молочной породы. У 28 животных в генотипе присутствуют «информативные» аллели, которые указывают на ассочиацию с маститом или резистентностью к данному заболеванию. У восприимчивых к заболеванию коров рассыпной тип обнаруживается у половины животных. Для здоровых коров более характерный магистральный тип выводной системы (35,7\%). У 9 коров с магистральным типом в генотипе оказываются только «положительные», а у 11 животных с рассыпным типом - только «отрицательные» аллели, что составляет, соответственно, 32,1 и 39,3\%. Сравнением наличия двух видов маркеров в группах здоровых и восприимчивых животных установлено два преобладаюших варианта:

- у здоровых животных чаще всего встречаются магистральный тип выводной системы вымени и хотя бы один аллель связанный с устойчивостью к маститам (9 случаев)

- у больных животных чаще всего встречаются рассыпной тип и хотя бы один аллель связанный с восприимчивостью $\kappa$ маститам (11 случаев).

Высокая частота выявления данных вариантов указывает на то, что существуют закономерные связи между типом выводной системы, аллелями BoLA-DRB3.2 и маститами.

Ключевые слова: коровы, мастит, главный комплекс гистосовместимости, ген BOLA-DRB3.2, аллели, тип выводной системы вымя, черно-пестрая порода.

\title{
Allelic polymorphism gene BOLA-DRB3.2 in connection with the types of excretory ducts udder and mastitis cows Ukrainian black-pied dairy breed
}

\author{
T. Suprovych, N. Suprovych, T. Karchevska, I. Chornyy, V. Chepurna \\ kokas2008@ukr.net \\ Podolsky State Agricultural and Technical University \\ T. Shevchenko Str., 13, Kamyanets-Podilskyi 32316, Ukraine
}

The results comparing the two types of markers associated with susceptibility (by resistance) cows to mastitis presented in the article. Previous studies indicated 2 markers. There are allele gene BOLA-DRB3.2 and placer or magistral type of excretory ducts udder. The study was conducted by identifying spectrum allele's and types of excretory ducts udder of cows in 47 Ukrainian Black Pied dairy breed. Some of the animals (28 caw) have in the genotype «informative» alleles that indicate association with mastitis or resistance to the disease. Susceptible cows to the disease often have a placer type (half of the animals). Healthy cows have oftener magistral type of main excretory system (35.7\%). With magistral type have genotype 9 cows "positive» alleles (32.1\%); 11 animals with placer type have only "negative» alleles (39.3\%). Comparing the presence of two types of markers in healthy and susceptible animals found two predominant choices:

- healthy animals have the oftener magistral type of excretory system of the udder, and at least one allele associated with resistance to mastitis (9 cases);

- in diseased animals have the oftener placer type of excretory system and at least one allele associated with susceptibility to mastitis (11 cases).

The high incidence of these options indicates that there are natural connections between the type of excretory ducts udder, by alleles BoLA-DRB3.2 and mastitis.

Key words: cows, mastitis, major histocompatibility complex, gene BOLA-DRB3.2, alleles, type of excretory ducts udder, blackpied breed.

\section{Вступ}

Сучасні досягнення молекулярної генетики зробили можливим ідентифікувати гени, що забезпечують формування господарсько-корисних ознак у великої рогатої худоби. Виявлення кращих алельних варіантів таких генів дозволить додатково до традиційних методів підбору і відбору тварин проводити селекцію 3 використанням маркерів на рівні ДНК. Одним 3 найбільш вагомих QTL-маркерів є ген $B o L A-D R B 3$, що кодує антигени класу II головного комплексу гістосумісності великої рогатої худоби. Молекули класу II розташовуються на поверхні В-клітин, які після внутрішньоклітинного процесінгу представляють чужорідні антигени Т-клітинам для забезпечення імунної відповіді гуморального типу. Відомо понад 100 алелів екзона 2 гена $B o L A-D R B 3$, які визначаються методом ПЛР-ПДРФ. Широкий поліморфізм даного гена обумовлений необхідністю зв'язування великої кількості чужорідних антигенів. На сьогодні щонайбільше досліджуються асоціації алельних варіантів гена $B o L A-$ $D R B 3$ з резистентністю до лейкозу і маститів (Sulim- ova, 2006; Sulimova et al., 2011; Suprovych and Suprovych, 2015).

Важливу роль в етіології захворювань вимені відіграють інтер'єрні характеристики, зокрема вивідна система вимені, яка відповідає за накопичення і виведення молока (Lozhkin and Solov'eva, 1992; Hussain et al., 2012). Вона бере участь у формуванні продуктивності, характеристиках молоковіддачі та стійкості до маститів (Lozhkin and Solov'eva, 1992, 1993; Solov'eva, 1997; Andreeva, 2007).

У віці 4 - 5 місяців елементи молочних протоків оформлюються в морфологічні види, а через $2-3$ місяці відбувається завершення диференціації ії структурних елементів на два типи: магістральний і розсипний. Результати прижиттєвої рентгенографії вивідної системи вимені у корів на протязі наступних лактацій свідчать про постійність морфологічного типу упродовж усього продуктивного використання тварин (Sizova, 2005). Це дає можливість розглядати тип вивідної системи вимені як морфологічний маркер стійкості та сприйнятливості корів до маститів. Досліджено, що у корів 3 магістральним типом вивідної 
системи вимені мастити виникають рідше, ніж при розсипному (Lozhkin and Solov'eva, 1993; Solov'eva, 1997).

Мета роботи. Дослідити розподіл алелів гена $B o L A-D R B 3.2$ при різних типах вивідної системи вимені у зв'язку з маститами.

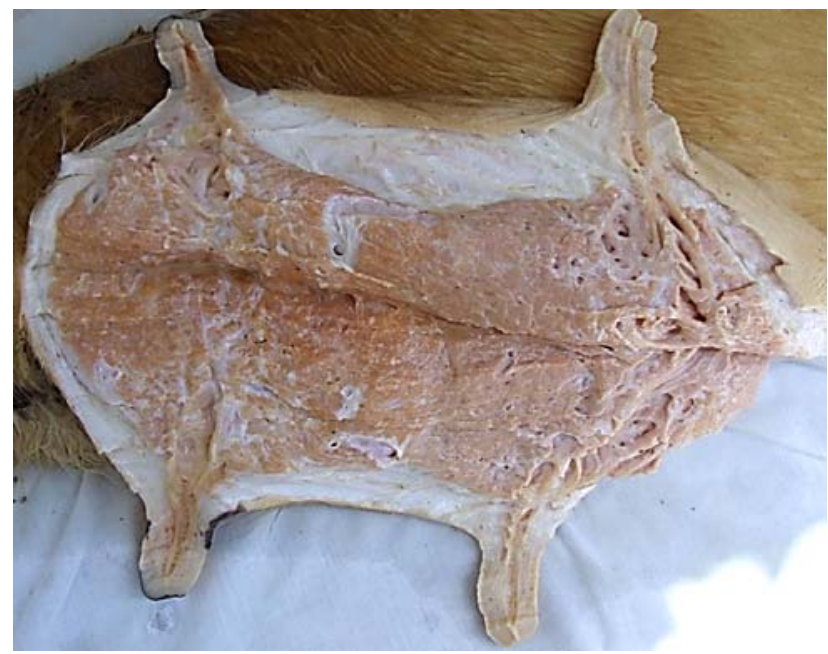

Рис. 1. Сагітальний розтин вимені корови для досліджень типу вивідної системи

\section{Матеріал і методи досліджень}

Об'єктом дослідження були зразки крові дійних корів різного віку української чорно-рябої молочної породи $(\mathrm{n}=47)$ господарств Хмельницької області, та молочні залози, відібрані після забою цих тварин.

Вивчення морфології вивідної системи проводили анатомічним препаруванням молочної залози, яке здійснювалося на свіжому матеріалі. Анатомічне препарування залоз проводилося за методикою проф. Ложкіна Е.Ф. (1993) в основі якої лежать сагітальні розтини кожної чверті окремо, із наступним препаруванням висхідних молочних протоків (Lozhkin and Solov'eva, 1993 ). Препарувалася не тільки кожна чверть вимені окремо, але й одночасно робився сагітальний розтин довгим ножем через верхівки дійок однієї половини
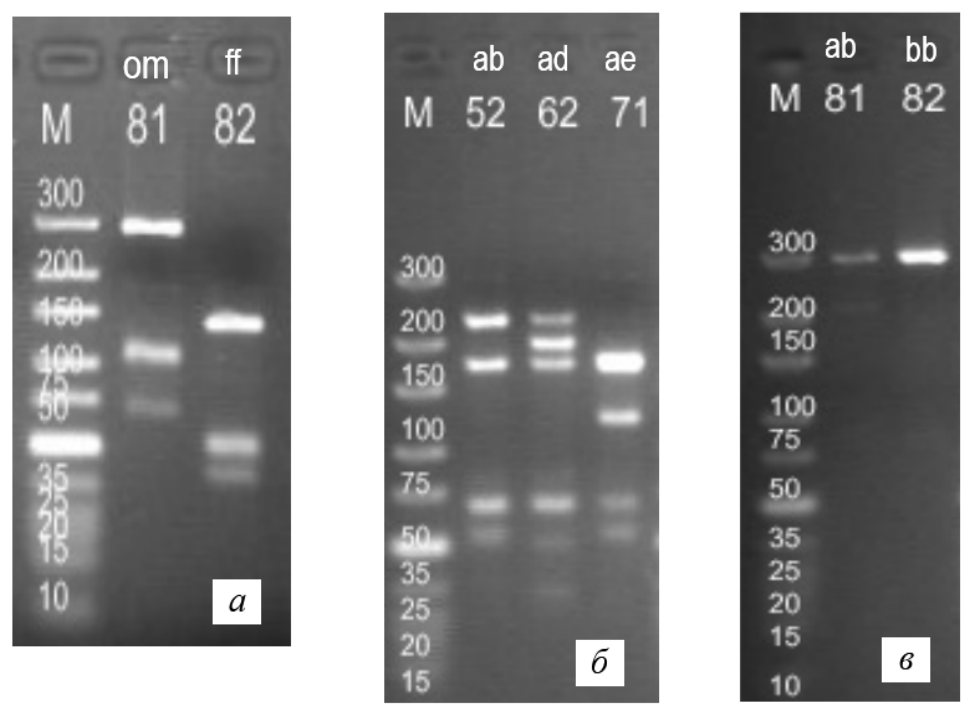

Рис. 2. Електрофореграми продуктів ампліфікації гена BoLA-DRB3.2, отриманих на ДНК корів української чорнорябої молочної породи з використанням різних ендонуклеаз: $\boldsymbol{a}$-RsaI; $\boldsymbol{\sigma}$-HaeIII; $\boldsymbol{b}-$ BstYI. Для оцінки довжин фрагментів використано маркер (M) молекулярних мас «GeneRuler ${ }^{\mathrm{TM}}$ Ultra Low Range DNA Ladder» фірми «Fermentas», Литва. Зверху вказані варіанти ДНК-патернів. 
В табл. 1 представлено результати дослідження 47 тварин, у яких визначено алелі $B o L A-D R B 3.2$, діагноз і тип вивідної системи вимені. В даній вибірці у 22 (46,8\%) корів встановлено гнійно-катаральний мастит, у $30(63,8 \%)$ - виявлено розсипний тип вивідної системи вимені. На темному фоні білими цифрами відмічено алелі, які асоціюються 3 маститами, жирними чорними цифрами - із резистентністю до захворювання. Всі інші алелі нейтральні.

Таблиия 1

Алельний спектр і тип вивідної системи у стійких та сприйнятливих до маститів корів української чорно-рябої молочної породи

\begin{tabular}{|c|c|c|c|c|c|}
\hline $\begin{array}{l}\text { № } \\
3 / \pi\end{array}$ & Вушний & Діагноз & \multicolumn{2}{|c|}{ Алелі } & Тип вивідної системи вимені \\
\hline 1. & 132 & мастит & 12 & 28 & розсипний \\
\hline 2. & 898 & мастит & 7 & 28 & розсипний \\
\hline 3. & 150 & здорова & 2 & 13 & магістральний \\
\hline 4. & 30 & здорова & 32 & 37 & магістральний \\
\hline 5. & 1228 & мастит & 10 & 28 & розсипний \\
\hline 6. & 103 & здорова & 16 & 36 & магістральний \\
\hline 7. & 136 & здорова & 22 & 8 & розсипний \\
\hline 8. & 60 & мастит & 26 & 11 & розсипний \\
\hline 9. & 860 & мастит & 26 & 26 & розсипний \\
\hline 10. & 364 & здорова & 10 & 10 & магістральний \\
\hline 11. & 1094 & здорова & 10 & 10 & магістральний \\
\hline 12. & 4210 & мастит & 23 & 26 & розсипний \\
\hline 13. & 874 & мастит & 24 & 24 & розсипний \\
\hline 14. & 36 & здорова & 22 & 31 & магістральний \\
\hline 15. & 914 & здорова & 8 & 8 & магістральний \\
\hline 16. & 132 & мастит & 22 & 26 & розсипний \\
\hline 17. & 898 & мастит & 24 & 10 & розсипний \\
\hline 18. & 794 & здорова & 13 & 23 & магістральний \\
\hline 19. & 5142 & мастит & 7 & 26 & розсипний \\
\hline 20. & 4726 & здорова & 22 & 22 & розсипний \\
\hline 21. & 8143 & мастит & 2 & 28 & розсипний \\
\hline 22. & 6889 & здорова & 22 & 37 & магістральний \\
\hline 23. & 7684 & здорова & 3 & 13 & магістральний \\
\hline 24. & 7522 & мастит & 7 & 28 & розсипний \\
\hline 25. & 6896 & мастит & 1 & 48 & розсипний \\
\hline 26. & 6583 & здорова & 8 & 20 & розсипний \\
\hline 27. & 7763 & здорова & 13 & 23 & магістральний \\
\hline 28. & 7286 & здорова & 8 & 8 & магістральний \\
\hline 29. & 5488 & здорова & 8 & 24 & розсипний \\
\hline 30. & 5411 & мастит & 3 & 11 & розсипний \\
\hline 31. & 6445 & здорова & 4 & 24 & магістральний \\
\hline 32. & 6425 & мастит & 8 & 21 & розсипний \\
\hline 33. & 5821 & мастит & 3 & 24 & розсипний \\
\hline 34. & 4732 & мастит & 7 & 28 & розсипний \\
\hline 35. & 5318 & мастит & 22 & 22 & розсипний \\
\hline 36. & 8207 & мастит & 12 & 28 & розсипний \\
\hline 37. & 4753 & здорова & 7 & 36 & магістральний \\
\hline 38. & 8506 & мастит & 3 & 11 & розсипний \\
\hline 39. & 5248 & здорова & 36 & 37 & магістральний \\
\hline 40. & 8117 & мастит & 15 & 37 & розсипний \\
\hline 41. & 8472 & здорова & 4 & 7 & магістральний \\
\hline 42. & 9578 & здорова & 13 & 23 & магістральний \\
\hline 43. & 5606 & мастит & 3 & 48 & розсипний \\
\hline 44. & 4738 & мастит & 15 & 24 & розсипний \\
\hline 45. & 7030 & мастит & 32 & 41 & розсипний \\
\hline 46. & 5533 & мастит & 7 & 18 & розсипний \\
\hline 47. & 4889 & здорова & 10 & 10 & розсипний \\
\hline
\end{tabular}


Для того, щоб встановити наявність або відсутність зв'язку між типом вивідної системи вимені, алелями гена $B O L A-D R B 3.2$, стійкістю чи сприйнятливістю до маститів, з подальшого аналізу вилучені тварини, у генотипі яких виявлено нейтральні алелі даного гена. В цьому випадку дослідна вибірка скорочується до 28 корів.

В новій вибірці співвідношення хворих і здорових тварин дещо змінюється і складає по 14 тварин. Змінюється й співвідношення типів вивідної системи. В даній вибірці 18 або 64,3\% корів мають розсипний тип молочної залози.
Порівняння аналогічних співвідношень дослідних вибірок з нейтральними генотипами й без них показує, що суттєвої різниці між якісними показниками в альтернативних парах хвора/здорова корова і розсипний/магістральний тип не має. Це дає можливість поширити висновки дослідження на все стадо.

Впорядкуємо табл. 1 таким чином, щоб у верхній частині ліворуч розташувалися здорові тварини 3 наявними алелями, а праворуч - 3 магістральними типом вивідної системи (табл. 2). Відповідно в нижній частині таблиці розташовано хворих тварин і з розсипним типом вимені.

Таблиия 2

Спектр «значимих» алелів за діагнозом і типом вивідної системи вимені

\begin{tabular}{|c|c|c|c|c|c|c|c|}
\hline \multirow{2}{*}{$\begin{array}{c}\text { Вушний } \\
\text { номер }\end{array}$} & \multirow{2}{*}{$\begin{array}{l}\text { Діагноз } \\
\text { здорова }\end{array}$} & \multicolumn{4}{|c|}{ Алелі BoLA-DRB3.2 } & \multirow{2}{*}{$\begin{array}{c}\text { Тип вивідної системи } \\
\text { магістральний }\end{array}$} & \multirow{2}{*}{$\begin{array}{c}\begin{array}{c}\text { Вушний } \\
\text { номер }\end{array} \\
150\end{array}$} \\
\hline & & 2 & 13 & 2 & 13 & & \\
\hline 136 & здорова & 22 & 8 & 22 & 31 & магістральний & 36 \\
\hline 36 & здорова & 22 & 31 & 8 & 8 & магістральний & 7286 \\
\hline 914 & здорова & 8 & 8 & 13 & 23 & магістральний & 794 \\
\hline 794 & здорова & 13 & 23 & 22 & 37 & магістральний & 6889 \\
\hline 4726 & здорова & 22 & 22 & 3 & 13 & магістральний & 7684 \\
\hline 6889 & здорова & 22 & 37 & 13 & 23 & магістральний & 7763 \\
\hline 7684 & здорова & 3 & 13 & 8 & 8 & магістральний & 914 \\
\hline 6583 & здорова & 8 & 20 & 4 & 24 & магістральний & 6445 \\
\hline 9578 & здорова & 13 & 23 & 13 & 23 & магістральний & 9578 \\
\hline 7286 & здорова & 8 & 8 & 22 & 8 & розсипний & 136 \\
\hline 5488 & здорова & 8 & 24 & 22 & 22 & розсипний & 4726 \\
\hline 6445 & здорова & 4 & 24 & 8 & 20 & розсипний & 6583 \\
\hline 7763 & здорова & 13 & 23 & 8 & 24 & розсипний & 5488 \\
\hline 60 & мастит & 26 & 11 & 26 & 11 & розсипний & 60 \\
\hline 860 & мастит & 26 & 26 & 26 & 26 & розсипний & 860 \\
\hline 4210 & мастит & 23 & 26 & 23 & 26 & розсипний & 4210 \\
\hline 874 & мастит & 24 & 24 & 24 & 24 & розсипний & 874 \\
\hline 132 & мастит & 22 & 26 & 22 & 26 & розсипний & 132 \\
\hline 898 & мастит & 24 & 10 & 24 & 10 & розсипний & 898 \\
\hline 5142 & мастит & 7 & 26 & 7 & 26 & розсипний & 5142 \\
\hline 6896 & мастит & 1 & 48 & 1 & 48 & розсипний & 6896 \\
\hline 6425 & мастит & 8 & 21 & 8 & 21 & розсипний & 6425 \\
\hline 5821 & мастит & 3 & 24 & 3 & 24 & розсипний & 5821 \\
\hline 5318 & мастит & 22 & 22 & 22 & 22 & розсипний & 5318 \\
\hline 5606 & мастит & 3 & 48 & 3 & 48 & розсипний & 5606 \\
\hline 4738 & мастит & 15 & 24 & 15 & 24 & розсипний & 4738 \\
\hline 5533 & мастит & 7 & 18 & 7 & 18 & розсипний & 5533 \\
\hline
\end{tabular}

3 табл. 2 маємо, що у здорових тварин магістральний тип вивідної системи трапляється 10 разів або в $35,7 \%$ випадків. У сприйнятливих корів розсипний тип зустрічається у половини досліджених корів і лише у 4 здорових (14,3\%). Це підтверджує висновки зроблені раніше в дослідженнях проф. Е. Ложкіна і Л. Соловйо- вої , що у корів з магістральним типом вивідної системи вимені мастити виникають рідше, ніж при розсипному (Lozhkin and Solov'eva, 1993; Solov'eva, 1997).

У 9 корів з магістральним типом вивідної системи в генотипі виявляються лише «позитивні», а у 11 тварин $з$ розсипним типом - лише «негативні» алелі, що 
складає, відповідно, 32,1 та 39,3\%. У однієї корови (в/н 6445) з магістральним типом в генотипі присутній «негативний алель *24, у 5 корів (в/н 136, 4726, 6583,6425 і 5318) з розсипним типом виявляються «позитивні» алелі, і лише у 2 тварин (в/н 132 і 5488) в генотипі присутні протилежні за впливом алелі. Отже маємо переважаючу кількість алелів, які визначають стійкість до маститів, у корів 3 магістральним типом вивідної системи і навпаки, у тварин з розсипним типом частіше визначаються «негативні» алелі.

Маючи три ознаки можна отримати наступні варіанти їх взаємного впливу (табл. 3).

Табличя 3

\section{Частка різних варіантів між типом вивідної системи вимені та алелями BoLA-DRB3.2 у сприйнятливих} та резистентних до маститу корів

\begin{tabular}{|c|c|c|c|c|c|}
\hline \multirow[b]{2}{*}{. } & \multicolumn{3}{|c|}{ Типи варіантів } & \multirow[b]{2}{*}{$\begin{array}{l}\text { Кількість } \\
\text { варіантів }\end{array}$} & \multirow[b]{2}{*}{ Частка, \% } \\
\hline & діагноз & $\begin{array}{c}\text { алелі } \\
\text { (+ «позитивні» } \\
- \text { «негативні») }\end{array}$ & тип вивідної системи & & \\
\hline 1 & здорова & + & магістральний & 9 & 32,1 \\
\hline 2 & здорова & + & розсипний & 3 & 10,7 \\
\hline 3 & здорова & - & магістральний & 1 & 3,62 \\
\hline 4 & здорова & - & розсипний & - & - \\
\hline 5 & мастит & + & магістральний & - & - \\
\hline 6 & мастит & + & розсипний & 2 & 7,14 \\
\hline 7 & мастит & - & магістральний & - & - \\
\hline 8 & мастит & - & розсипний & 11 & 39,3 \\
\hline 9 & \multicolumn{3}{|c|}{ інші } & $2 *$ & 7,14 \\
\hline \multicolumn{4}{|c|}{ всього } & 28 & 100 \\
\hline
\end{tabular}

*У корів 3 в/н 132 і 5488 в генотипі присутні протилежні за впливом алелі

Отже, маємо два переважаючих варіанти:

$1-$ у здорових тварин найчастіше зустрічаються магістральний тип вивідної системи вимені і хоча б один алель пов'язаний зі стійкістю до маститів;

8 - у хворих корів найчастіше зустрічаються розсипний тип вивідної системи вимені і хоча б один алель пов'язаний зі сприйнятливістю до маститів.

Інші варіанти сумарно складають лише $28,5 \%$.

\section{Висновки}

Збіг трьох ознак у більш ніж у 30\% випадків при 8 можливих варіантах (по 12,5\% на один варіант) вказує на те, що існують закономірні зв'язки між типом вивідної системи, алелями $B o L A-D R B 3.2$ і можливими альтернативними станами вимені з огляду на можливість захворювання корів української чорно-рябої молочної породи на мастит.

Перспективи подальших досліджень. Необхідно розширити масив дослідження по кількості тварин, адже тоді буде можливо віднайти кореляційні зв'язки між типом вивідної системи вимені, алелями та стійкістю і сприйнятливістю корів до маститів.

\section{Бібліографічні посилання}

Sulimova, G.E., Lazebnaja, I.V., Perchun, A.V., Voronkova, V.N., Ruzina, M.N., Badin, G.A. (2011). Unikal'nost' kostromskoj porody krupnogo rogatogo skota s pozicii molekuljarnoj genetiki [Uniqueness of Kostroma breed of cattle from a position of molecular genetics]. Dostizhenija nauki i tehniki APK, 9, 52-54. (in Russian).

Sulimova, G.E. (2006). DNK-markery v izuchenii genofonda porod krupnogo rogatogo skota [DNA markers in the study of the gene pool of breeds of cat- tle]. Genofondy sel'skohozjajstvennyh zhivotnyh: geneticheskie resursy zhivotnovodstva. Moscaw: Nauka, 138-166 (in Russian).

Zagorodnij, A.P., Rudy`k, I.A., Nedvy`ga, M.M., Oleshko, V.P. (2006). Selekciya molochnoyi xudoby`za produkty`vnistyu ta stijkistyu do masty`tu [Breeding dairy cattle productivity and resistance to mastitis]. Visny`k Bilocerkivs`kogo derzh. agrar. un-tu. - Bila Cerkva, 42, 21-23 (in Ukrainian).

Lozhkin, Je.F., Solov'eva, L.P. (1993). Osobennosti razvitija vyvodnoj sistemy vymeni telok krasnoj stepnoj porody v pervyj mesjac zhizni [Features of the type of excretory ducts udder of red steppe breed in the first month of life]. Uchenye agrarniki sel'skohozjajstvennomu proizvodstvu. Kostroma, 51-52 (in Russian).

Lozhkin, Je.F., Solov'eva, L.P. (1992). Vzaimosvjaz' inter'era vymeni s molochnoj produktivnost'ju u korov kostromskoj porody [The relationship of the interior of the udder with milk production in cows of Kostroma breed]. Povyshenie molochnoj i mjasnoj produktivnosti v zhivotnovodstve. Moscow, 91-94 (in Russian).

Riaz Hussain, M., Tariq Javed, Ahrar Khan, Fazal Mahmood \& Razia Kausar. (2012). Mastitis and Associated Histo-pathological Consequences in the Context of Udder. Morphology Intern. J. of Agriculture \& Biology. 14, 947-952.

Andreeva, Z.P. (2007). Tipy stroenija vyvodnoj sistemy vymeni korov [Structure types excretory system of cows udder]. Vidovaja, vozrastnaja, tipovaja i porodnaja morfologija molochnoj zhelezy zhivotnyh v norme i patologii : pod red. L.I. Drozdovoj. Ekaterinburg: Izd. UrGSHA, 23-25 (in Russian).

Solov'eva, L.P. (1997). Vozmozhnosti ispol'zovanija morfologii vyvodnoj sistemy pri formirovanii vysokoproduktivnogo stada korov [The possibility of using the 
morphology of the excretory system udder in the formation of highly productive herd of cows]. Aktual'nye problemy nauki v APK. Kostroma. 88 (in Russian).

Sizova, O.O. (2005). Gistologicheskoe stroenie molochnoj zhelezy laktiruyushhix korov-pervotelok kostromskoj porody [Histological structure of the mammary gland of lactating fresh cow of Kostroma breed] Aktual'nye problemy nauki v APK: mater. 56-oj mezhd. nauch.prakt. konf. Kostroma, 139 (in Russian).

Suprovych, T.M. (2015). Asotsiatyvnyy zv"yazok mizh alelyamy hena BOLA-DRB3.2 ta mastytamy [Associative link between alleles BoLA-DRB3.2 gene and mastitis] Nauk. Visn. LNUVMBT imeni S.Z. Gzhyts'koho. - L'viv, 17, 2(62), 230-235 (in Ukrainian).

Behl, J.D., Verma, N.K., Tyagi, N., Mishra, P., Behl, R., Joshi, B.K. (2012). The Major Histocompatibility Complex in Bovines: A Review. Int. Scholarly Res. Network : ISRN Veterinary Science. Article ID $872710,12$.

Rupp, R., Hernandez, A., Mallard, B.A. (2007). Association of bovine leukocyte antigen (BoLA) DRB3.2 with immune response, mastitis, and production and type traits in Canadian Holsteins. J. Dairy Sci. 90(2), 10291038.

Galal, K., Hameed, A., Sender, G., Mayntz, M. (2006). Major histocompatibility complex polymorphism and mastitis resistance - a review. Animal Sci. Papers and Reports. 24(1), 11-25.

Sulimova, G.E., Zinchenko, V.V. (2011). Analiz polimorfizma DNK $\mathrm{s}$ ispol'zovaniem metoda polimeraznoj cepnoj reakcii [Analysis of DNA polymorphism using by PCR method] metodicheskoe posobie $\mathrm{k}$ praktikumu «DNK-markery dlya geneticheskoj pasportizacii i uluchsheniya genomov zhivotnyx xozyajstvenno cennyx vidov». Moscow: Cifrovichok, 94 (in Russian).

Misajlov, V.D., Nezhdanov, A.G., Parikov, V.A., Pritykin, N.V., Klimov, N.T., Meshheryakov, N.P., Vostroilova, G.A., Zharkoj, B.L. (2005). Metodicheskie rekomendacii po diagnostike, terapii i profilaktike subklinicheskogo mastita u korov v suxostojnyj period [Guidelines for the diagnosis, therapy and prevention of subclinical mastitis in cows in the dry period] Vseros. nauch.-issl. veterinarnyj institut patologii, farmakologii i terapii. - Voronezh, 11 (in Russian).

Suprovych, T., Suprovych, M. (2015). The impact study of antigens class I BOLA-A and alleles gene BOLADRB3 MHC system for stability and cows susceptibility to mastitis. Wschodnioeuropejskie Czasopismo Naukowe (East European Scientific Journal). Warszawa. 3, 94-98.

Стаття надійшла до редакції 11.09.2016 